\title{
PENGARUH MEDIA PENYAJIAN MATERI BELAJAR GURU (MODEL HIDUP) DAN VIDEO COMPACT DISK TERHADAP PRESTASI BELAJAR PENCAK SILAT KATEGORI TUNGGAL DITINJAU DARI KEMAMPUAN GERAK (MOTOR ABILITY)
}

\section{Oleh : Edi Purnomo1}

\begin{abstract}
Abstrak : Tujuan penelitian ini untuk mengetahui : (1) Perbedaan pengaruh media penyajian materi belajar guru (model hidup) dan video compak disk (VCD) terhadap prestasi belajar pencak silat kategori tunggal. (2) Perbedaan pengaruh prestasi belajar pencak silat kategori tunggal antara mahasiswa yang mempunyai kemampuan gerak tinggi dan kemampuan gerak rendah. (3) Pengaruh interaksi antara pengguanaan media penyajian materi belajar dan kemampuan gerak terhadap prestasi belajar pencak silat kategori tunggal.

Penelitian menggunakan metode eksperimen dengan rancangan factorial $2 \times 2$. Populasi penelitian adalah mahasiswa putera jurusan pendidikan, olahraga dan kesehatan pada program studi penkepor yang mengambil mata kuliah pencak silat II yang berjumlah 60 mahasiswa. teknik sampling yang digunakan adalah purposive random sampling, sampling yang diambil sebanyak 40 mahasiswa, sampel terdiri dari 20 mahasiswa yang mempunyai kemampuan gerak tinggi dan 20 mahasiswa yang mempunyai kemampuan gerak rendah. Variabel yang diteliti yaitu variabel bebas terdiri dari dua faktor yaitu variabel manipulatif dan variabel atributif serta (1) variabel terikat. Variabel manipulatif terdiri dari media penyajian materi belajar guru (model hidup) dan video compak disk (VCD). Variabel atributif terdiri dari kelompok sampel dengan kemampuan gerak tinggi dan rendah. Variabel terikat pada penelitian ini adalah prestasi belajar pencak silat kategori tunggal. Teknik pengumpulan data dengan tes dan pengukuran. Pengambilan data prestasi belajar pencak silat kategori tunggal dengan tes baku prestasi pencak silat kategori tunggal dari pb ipsi. Pengambilan kemampuan gerak dilakukan dengan Borrow Motor Ability test. Teknik analisis data penelitian ini menggunakan analisis varians dan uji rentang Newman Keuls, pada taraf signifikansi $5 \%$.
\end{abstract}

${ }^{1}$ Edi Purnomo : Dosen Program Studi Penjaskesrek FKIP Untan 
Kesimpulan: (1) Ada perbedaan pengaruh yang signifikan antara penggunaan media penyajian materi belajar guru (model hidup) dan video compact disk terhadap prestasi belajar pencak silat kategori tunggal. Pengaruh penyajian materi belajar video compact disk lebih baik dari pada guru (model hidup). (2) Ada perbedaan yang signifikan prestasi belajar pencak silat kategori tunggal antara mahasiswa yang memiliki kemampuan gerak tinggi dengan kemampuan gerak rendah. Prestasi belajar pencak silat kategori tunggal pada mahasiswa yang memiliki kemampuan gerak tinggi lebih baik dari pada yang memiliki kemampuan gerak rendah. (3) Terdapat pengaruh interaksi yang signifikan antara penggunaan media penyajian materi belajar dan tingkat kemampuan gerak terhadap prestasi belajar pencak silat kategori tunggal: (a)Mahasiswa yang memiliki kemampuan gerak tinggi lebih cocok jika diberikan penyajian materi belajar video compact disk. (b)Mahasiswa dengan kemampuan gerak rendah lebih cocok jika diberikan penyajian materi belajar guru (model hidup).

Kata Kunci : Media Penyajian Guru, Video Compact Disk, Model Hidup, Kemampuan Gerak, Prestasi Belajar Pencak Silatl.

\section{Pendahuluan}

\section{A. Latar Belakang Masalah}

Perkembangan olahraga semakin hari semakin meningkat, terbukti semakin banyak para atlet yang memecahkan rekor dalam setiap prestasi atau pertandingan-pertandingan baik tingkat nasional maupun internasional. Sejalan dengan perkembangan prestasi atlet tidak terlepas dari banyak faktor yang mendukung, baik sarana prasarana dan peralatan olahraga serta sistem kompetisi yang ada, selain itu keadaan anatomis atlet, kondisi physiologis, kemampuan fisik, ketrampilan teknik, dan pemahaman taktik dan strategi.

Pencak silat merupakan olahraga asli Indonesia peninggalan warisan leluhur yang wajib kita lestarikan. Perkembangan pencak silat menunjukan kemajuan yang sangat besar, terbukti semakin banyaknya pertandinganpertandingan yang diselenggarakan baik ditingkat SD, SLTP, SMU dan SMK (pelajar) dan perguruan tinggi. Baik dalam pertandingan POPNAS (Pekan Olahraga Pelajar Nasional), PON (Pekan OLahraga Nasional), SEA Games (kejuaraan wilayah asia tenggara) (Johansyah Lubis : 2004, 2-4), bahkan kejuaraan Dunia yang baru-baru ini diselengarakan di Jakarta dan tim Indonesia menjadi juara umum. 
Pencak silat merupakan suatu sistem pembelaan diri yang memiliki gerakan-gerakan yang unik melibatkan semua komponen tubuh manusia dengan jurus yaitu berupa rangkaian teknik-teknik dasar baik berupa tangkisan, pukulan, tendangan, tangkapan, jatuhan, dan bantingan. (Kotot Slamet Riyadi : 2003 : 3). Karena banyaknya tempat latihan atau perguruanperguruan pencak silat akan mempengaruhi teknik-teknik dasar dalam pencak silat. Setiap perguruan pencak silat mempunyai ciri, lambang dan nama teknik-teknik dasar yang berbeda-beda. Dalam induk organisai pencak silat atau IPSI dengan membatasi teknik-teknik yang berbahaya dalam pertandingan pencak silat.

"Gerakan pencak silat adalah suatu gerak terencana, terarah, terkoordinasi, dan terkendali yang mempunyai empat aspek yang merupakan satu kesatuan utuh dan tidak dapat dipisah-pisahkan".(Johansyah Lubis, 2004 : 7). Pencak silat terdiri dari pencak silat tanding (olahraga), pencak silat kategori tunggal, pencak silat kategori ganda dan pencak silat kategori beregu. Pencak silat kategori tunggal dipertandingan mulai dari SD sampai tingkat perguruan tinggi. Pencak silat tunggal yang terdiri dari rangkaian gerakan yang dapat merangsang motorik halus maupun motorik kasar. Prestasi pencak silat atlet Indonesia dikejuaraan dunia yang diselenggarakan di Jakarta tanggal 12-19 Desember 2010 mendapatkan juara1.

Prestasi yang sudah diraih hendaknya dipertahankan salah satunya dengan penyiapan bibit atlet sedini mungkin. Iklim pertandingan yang sehat dikalangan pelajar akan mecetak bibit atlet yang potensial. Pebinaan atlet usia dini memiliki sasaran para pelajar lewat pendidikan jasmani. Toho Cholik M. \& Rusli Lutan (2001: 2) menyatakan, "Pendidikan jasmani merupakan bagian dari pendidikan secara umum. Pendidikan jasmani dapat didefinisikan sebagai suatu proses pendidikan yang ditujukan untuk mencapai tujuan pendidikan melalui gerakan fisik. Pendidikan sebagai salah satu sub sistem pendidikan yang berperan yang penting dalam mengembangkan kualitas manusia Indonesia". Dalam KTSP (Diknas : 2006:1) dijelaskan bahwa "Pendidikan jasmani dan kesehatan bertujuan untuk mengembangkan aspek kebugaran jasmani, keterampilan gerak, keterampilan berfikir kritis, keterampilan sosial, penalaran, stabilitas emosional, tindakan moral, aspek pola hidup sehat, dan pengenalan lingkungan hidup bersih melalui aktivitas jasmani, olahraga dan kesehatan jasmani terpilih yang direncanakan secara sistematis dalam rangka mencapai tujuan pendidikan nasional".

Berdasarkan pendapat di atas dapat disimpulkan bahwa pendidikan jasmani terdiri dari aspek psikomotor, aspek afektif dan aspek kognitif. 
Aspek psikomotor yang terdiri dari domain motorik, sedangkan domain afektif (pergaulan, sosial dan kejujuran) dan aspek kognitif (kedisiplinan, kepatuhan). Upaya untuk mengembangkan ketiga aspek tersebut sudah diatur dalam kurikulum macam-macam cabang olahraga. Pertumbuhan dan perkembangan dari aspek psikomotor, afektif dan kogniti tersebut harus merata dan tidak terpisah-pisah.

Guru menjadi kunci keberhasilan dalam mengajar pendidikan jasmani. Guru mempunyai peranan yang sangat penting dalam pendidikan jasmani, peranan guru tidak hanya pada saat proses belajar berlangsung tetapi juga sebelum dan sesudahnya. (Sugiyanto, 1999: 112). Sebelum mengajar guru harus membuat persiapan-persiapan yang mendukung pelaksanaan yang sistematis. Dalam mengajar hendaknya diciptakan kondisi yang mendukung proses belajar siswa, baik minat dan menumbuhkan motivasi. Guru yang profesional selalu berupaya meningkatkan pengetahuan, keterampilan dan pengalaman praktis maupun teoritis. Dalam mengajar guru dituntut dapat menciptakan pembelajaran yang menarik dan menyenangkan. Salah satu lewat bantuan perkembangan teknologi melalui media pembelajaran. Media pembelajaran adalah perpaduan antara bahan dan alat atau perpaduan antara software dan hardware (Sadiman, dkk dalam bambang warsita (2008: 122). Sudjana (2005: 112-163) mengemukakan bahwa: "Ada 16 teknik partisipatif yang dilaksanakan oleh guru, yaitu (1) teknik simulasi; (2) teknik studi kasus; (3) teknik cerita pemula diskusi (discussion starrer stori); teknik kelompok buzz (buzz group); (6) teknik situasi hipotesis (Hypotetical situation technique); (7) teknik forum; (8) teknik bermain peran (role play); (9) teknik permainan (games); (10) teknik penggunaan alat bantu pandang (visual aids/audio visual); (11) teknik ceramah bervariasi; (12) teknik kunjungan lapangan (field visit technique); (13) teknik diskripsi, interprestasi dan evaluasi; (14) media model hidup, (15) teknik praktik lapangan; (16) teknik kerja kelompok".

Sedangkan menurut Rudy Bretz dalam Bambang Warsita (2008: 123124) : "medium audiovisual diperjelas dengan dibagi-bagi lagi lebih rinci menjadi (1) media audiovisual bergerak, (2) media audiovisual diam; (3) media visual gerak; (4) media visual diam; (5) media audio; (6) media cetak atau teks; selain itu , kita mengenal media transparansi, slide suara, media grafis, papan penyaji, permainan simulasi, film, $\mathrm{VCD} / \mathrm{CD}$, multimedia, internet dan lain-lain".

Menurut pendapat para pakar di atas penulis membatasi pendekatan pembelajaran dengan penyajian materi belajar oleh guru (model hidup) dan 
video compact disk (VCD). Alasan dipilihnya pendekatan pembelajaran tersebut bahwa pencak silat kategori tunggal adalah pertandingan pencak silat yang menampilkan seorang pesilat memperagakan kemahirannya dalam jurus baku tunggal secara benar, dan mantap penuh penjiwaan dengan tangan kosong dan senjata (Johansyah Lubis, 2004: 7).

Pendekatan pembelajaran dengan media penyajian materi oleh guru (model hidup) sering digunakan dalam pembelajaran pencak silat dan mempunyai kelebihan dan kekurangan. Mengingat kemajuan teknologi yang semakin pesat guru dituntut untuk tidak gagap teknologi yang semakin canggih. Dengan menggunakan pendekatan pembelajaran dengan penyajian materi belajar video compact disk (VCD) membantu guru dalam menyampaikan informasi yang telah tersusun agar pembelajaran lebih menarik. Diharapkan dengan pendekatan pembelajaran mempengaruhi prestasi belajar pencak silat kategori tunggal. Yang dimaksud prestasi belajar adalah perubahan perilaku yang terjadi setelah mengikuti proses belajar mengajar sesuai dengan tujuan pendidikan. ( Purwanto, 2008: 54).

Menggunakan media penyajian guru (model hidup) belum tentu lebih baik dibandingkan dengan menggunakan video compact disk (VCD) . Hal ini dipengaruhi oleh beberapa faktor diantaranya kemampuan gerak siswa, ketebalan otot, kekuatan jantung yang mendukung gerakan pencak silat kategori tunggal, sarana dan prasarana. Maka perlu diadakan penelitian dengan judul "Pengaruh media penyajian materi belajar guru (model hidup) dan video compact disk (VCD) terhadap prestasi belajar pencak silat kategori tunggal ditinjau dari kemampuan gerak dasar".

\section{B. Identifikasi Masalah}

Berdasarkan latar belakang yang telah dikemukakan di atas maka dapat diidentifikasi masalah sebagai berikut :

1. Pembelajaran olahraga yang baik tergantung dari seorang guru yang mengelola kelas dan memodifikasi sebuah pembelajaran

2. Guru sebagai model bagi siswa harus dapat memberikan pembelajaran olahraga yang baik.

3. Pembelajaran olahraga yang menarik dan menyenangkan salah satunya dengan menggunakan media penyajian materi belajar

4. Salah satu pendekatan media penyajian materi belajar dengan menggunakan Video Compact Disk (VCD)

5. Seberapa hebat pendekatan pembelajaran tergantung dari mahasiswa yang mempunyai kemampuan gerak dasar. 


\section{Pembatasan Masalah}

Mengingat banyaknya masalah dalam penelitian ini, maka peneliti membatasi pada :

1. Pengaruh media penyajian materi belajar guru (model hidup) dan video compact disk (VCD) terhadap prestasi belajar pencak silat kategori tunggal.

2. Pengaruh kemampuan gerak dasar tinggi dan kemampuan gerak dasar rendah terhadap prestasi belajar pencak silat kategori tunggal.

3. Pengaruh Interaksi media penyajian materi belajar dan kemampuan gerak dasar terhadap prestasi belajar pencak silat kategori tunggal.

\section{Perumusan Masalah}

Berdasarkan identifikasi masalah, pembatasan masalah maka dapat dirumuskan maslah sebagai berikut:

1. Adakah perbedaan pengaruh media penyajian materi belajar guru (model hidup) dan video compact disk (VCD) terhadap prestasi belajar pencak silat kategori tunggal?

2. Adakah perbedaan pengaruh prestasi belajar pencak silat kategori tunggal antara mahasiswa yang mempunyai kemampuan gerak dasar tinggi dan kemampuan gerak dasar rendah?

3. Adakah pengaruh interaksi antara pengguanaan media penyajian materi belajar dan kemampuan gerak dasar terhadap prestasi belajar pencak silat kategori tunggal?

\section{E. Tujuan Penelitian}

Berdasarkan permasalahan yang dikemukakan di atas, penelitian ini mempunyai tujuan untuk mengetahui :

1. Perbedaan pengaruh media penyajian materi belajar guru (model hidup) dan video compact disk (VCD) terhadap prestasi belajar pencak silat kategori tunggal.

2. Perbedaan pengaruh prestasi belajar pencak silat kategori tunggal antara mahasiswa yang mempunyai kemampuan gerak dasar tinggi dan kemampuan gerak dasar rendah.

Pengaruh interaksi antara pengguanaan media penyajian materi belajar dan kemampuan gerak dasar terhadap prestasi belajar pencak silat kategori tunggal. 


\section{F. Manfaat Penelitian}

Setelah selesai penelitian ini, hasil yang diperoleh nantinya diharapkan dapat memberikan manfaat kepada guru dan pelatih, sebagai :

1. Secara teorik untuk penelusuran yang mendalam mengenai variablevariabel pendukung yang turut mempengaruhi keberhasilan siswa dalam meningkatkan prestasi belajar pencak silat kategori tunggal

2. Memberikan sumbangan pengetahuan sebagai bahan pertimbangan para guru pendidikan jasmani, mengenai pantingnya media penyajian materi belajar dan kemampuan gerak dasar agar prestasi belajar pencak silat kategori tunggal dapat tercapai dengan maksimal

\section{G. Metode dan Rancangan Penelitian}

Metode penelitian yang digunakan dalam penelitian ini adalah metode eksperimental dengan rancangan factorial 2 x 2 (Sutrisno Hadi. 1987 :271). Desain faktorial ini disajikan dalam tabel berikut :

Tabel 1. Rancangan Penelitian Faktorial 2 X 2

\begin{tabular}{|l|c|c|}
\hline \multicolumn{1}{|c|}{ Manipulatif } & $\begin{array}{c}\text { Media penyajian guru } \\
\text { (model hidup) } \\
\text { atributif }\end{array}$ & $\begin{array}{c}\text { Media penyajian video } \\
\text { compact disk (VCD) } \\
\text { (a2) }\end{array}$ \\
\hline $\begin{array}{c}\text { Kemapuan gerak } \\
\text { dasar tinggi (b1) }\end{array}$ & $\mathrm{a}_{1} \mathrm{~b}_{1}$ & $\mathrm{a}_{2} \mathrm{~b}_{1}$ \\
\hline $\begin{array}{c}\text { Kemampuan gerak } \\
\text { dasar rendah (b2) }\end{array}$ & $\mathrm{a}_{1} \mathrm{~b}_{2}$ & $\mathrm{a}_{2} \mathrm{~b}_{2}$ \\
\hline
\end{tabular}

Keterangan:

$a_{1} b_{1}$ : kelompok pendekatan media penyajian guru (model hidup) dengan kemampuan gerak dasar tinggi.

$a_{1} b_{2}$ : kelompok pendekatan media penyajian video compact disk (VCD) dengan kemampuan gerak dasar tinggi.

$a_{2} b_{1}$ : kelompok pendekatan media penyajian guru (model hidup) dengan kemampuan gerak dasar rendah.

$a_{2} b_{2}:$ kelompok pendekatan media penyajian video compact disk (VCD) dengan kemampuan gerak dasar rendah.

\section{H. Hasil Penelitian}

Dalam bab ini disajikan mengenai hasil penelitian beserta interpretasinya. Penyajian hasil penelitian adalah berdasarkan analisis statistik yang dilakukan pada tes awal dan tes akhir prestasi belajar pencak silat kategori tunggal. Berturut-turut berikut disajikan mengenai deskripsi 
data, uji persyaratan analisis, pengujian hipotesis dan pembahasan hasil penelitian.

Deskripsi hasil analisis data hasil tes prestasi belajar pencak silat kategori tunggal tiap kelompok yang dibandingkan disajikan sebagai berikut: Tabel 2. Deskripsi Data Prestasi Belajar Pencak Silat Kategori Tunggal Tiap Kelompok Berdasarkan Penggunaan Media Penyajian Materi

Belajar Dan Tingkat Kemampuan Gerak Dasar.

\begin{tabular}{|c|c|c|c|c|}
\hline \multirow{2}{*}{$\begin{array}{c}\text { Tingkat } \\
\text { Kemampuan } \\
\text { Gerak Dasar }\end{array}$} & Statistik & $\begin{array}{c}\text { Penyajian Materi } \\
\text { Belajar Guru } \\
\text { (Model Hidup) }\end{array}$ & $\begin{array}{c}\text { Penyajian Materi } \\
\text { Belajar Video } \\
\text { Compact Disk }\end{array}$ & Total \\
\hline \multirow{2}{*}{ Tinggi } & $\mathrm{N}$ & 10 & 10 & 20 \\
\cline { 2 - 5 } & Rerata & 425,90 & 451,90 & 438,90 \\
\hline \multirow{2}{*}{ Rendah } & $\mathrm{N}$ & 10 & 10 & 20 \\
\cline { 2 - 5 } & Rerata & 427,40 & 424,70 & 426,05 \\
\hline \multirow{2}{*}{ Total } & $\mathrm{N}$ & 20 & 20 & 40 \\
\cline { 2 - 5 } & Rerata & 426,65 & 438,30 & 432,475 \\
\hline
\end{tabular}

Kelompok perlakuan menggunakan media penyajian materi belajar guru (model hidup) dan video compact disk memberikan pengaruh terhadap prestasi belajar pencak silat kategori tunggal yang berbeda. Jika antara kelompok mahasiswa yang mendapat penyajian materi belajar guru (model hidup) dan dengan penyajian materi belajar video compact disk dibandingkan, maka dapat diketahui bahwa kelompok perlakuan penyajian materi belajar video compact disk memiliki prestasi belajar pencak silat kategori tunggal sebesar 11.65 lebih tinggi dari pada kelompok penyajian materi belajar guru (model hidup). Gambaran nilai rata-rata prestasi belajar pencak silat kategori tunggal antara kelompok perlakukan dengan penyajian materi belajar guru (model hidup) dan video compact disk dapat dibuat histogram perbandingan nilai-nilai sebagai berikut:

Gambar 1. Histogram Nilai Rata-Rata Prestasi Belajar Pencak Silat Kategori Tunggal Kelompok Penyajian Materi Belajar Guru (Model Hidup) Dan Video Compact Disk 


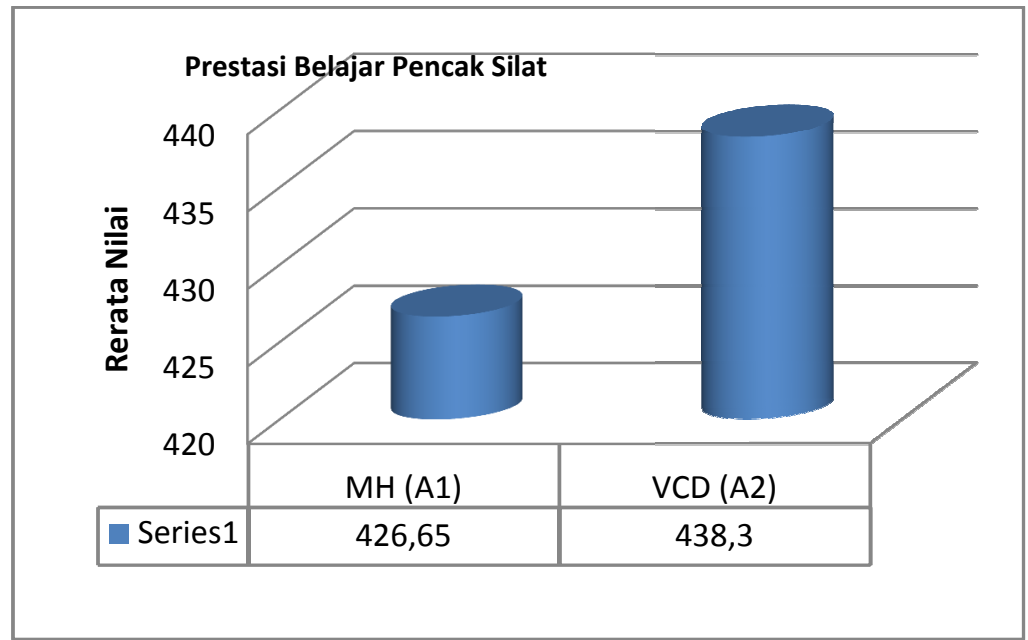

Keterangan :

$\mathrm{MH}=$ Kelompok penyajian materi belajar guru (model hidup) langsung $\mathrm{VCD}=$ Kelompok penyajian materi belajar video compact disk

\begin{tabular}{|c|c|c|}
\hline No & $\begin{array}{c}\text { Kelompok Perlakuan } \\
(\text { Sel) }\end{array}$ & $\begin{array}{c}\text { Nilai Prestasi belajar Pencak Silat } \\
\text { Kategori Tunggal }\end{array}$ \\
\hline 1 & $\mathrm{~A}_{1} \mathrm{~B}_{1}\left(\mathrm{KP}_{1}\right)$ & 425,90 \\
\hline 2 & $\mathrm{~A}_{1} \mathrm{~B}_{2}\left(\mathrm{KP}_{2}\right)$ & 427,40 \\
\hline 3 & $\mathrm{~A}_{2} \mathrm{~B}_{1}\left(\mathrm{KP}_{3}\right)$ & 451,90 \\
\hline 4 & $\mathrm{~A}_{2} \mathrm{~B}_{2}\left(\mathrm{KP}_{4}\right)$ & 424,70 \\
\hline
\end{tabular}

Jika antara kelompok mahasiswa yang memiliki kemampuan gerak dasar tinggi dan rendah dibandingkan, maka dapat diketahui bahwa kelompok mahasiswa yang memiliki kemampuan gerak dasar tinggi memiliki prestasi belajar pencak silat kategori tunggal sebesar 12.85 lebih tinggi dari pada kelompok mahasiswa yang memiliki kemampuan gerak dasar rendah. Gambaran nilai rata-rata prestasi belajar pencak silat kategori tunggal antara kelompok mahasiswa yang memiliki kemampuan gerak dasar tinggi dan rendah dapat dibuat histogram perbandingan nilai-nilai sebagai berikut: 


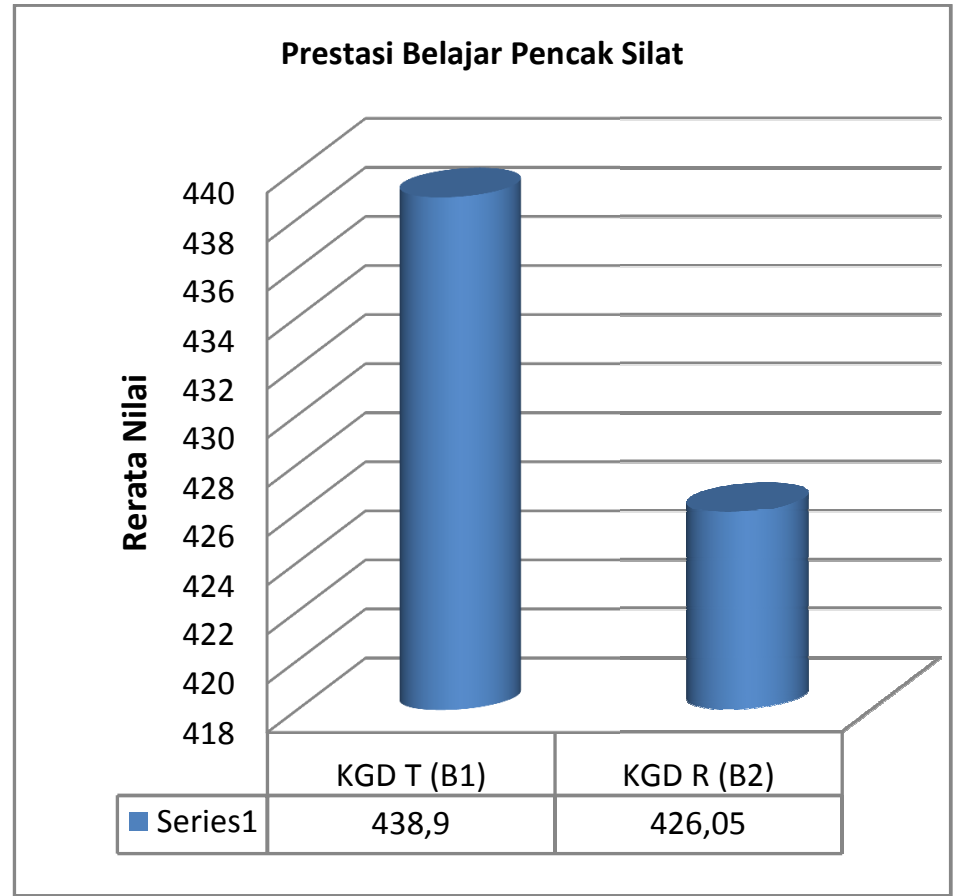

Gambar 2. Histogram Nilai Rata-Rata Prestasi Belajar Pencak Silat Kategori Tunggal Kelompok Mahasiswa Yang Memiliki Kemampuan Gerak Dasar Tinggi Dan Rendah

Keterangan :

KGD T = Kelompok kemampuan gerak dasar tinggi

KGD R = Kelompok kemampuan gerak dasar rendah

Masing-masing sel (kelompok perlakuan) memiliki prestasi belajar pencak silat kategori tunggal yang berbeda. Nilai prestasi belajar pencak silat kategori tunggal masing-masing sel (kelompok perlakuan) dapat dilihat pada tabel berikut.

Tabel 2. Nilai Prestasi Belajar Pencak Silat Kategori Tunggal MasingMasing Sel (Kelompok Perlakuan)

Nilai rata-rata prestasi belajar pencak silat kategori tunggal yang dicapai tiap kelompok perlakuan disajikan dalam bentuk histogram sebagai berikut: 


\section{Prestasi Belajar Pencak Sllat}

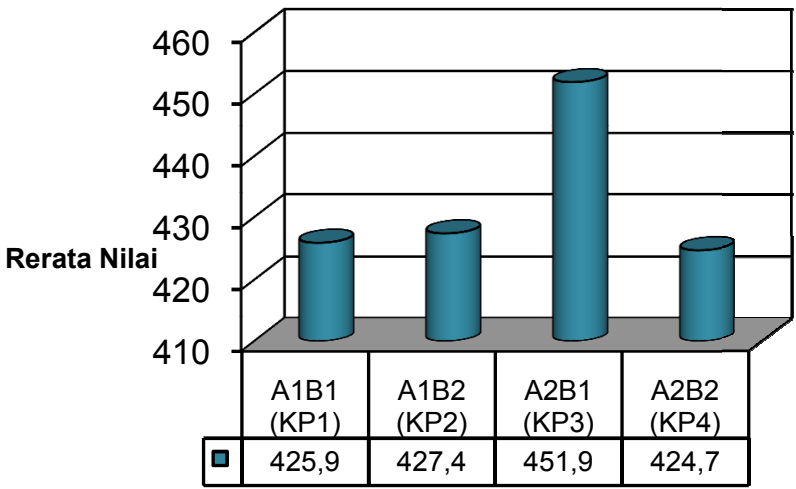

\section{Kelompok}

Gambar 3. Histogram Nilai Rata-rata Prestasi Belajar Pencak Silat Kategori Tunggal Pada Tiap Kelompok Perlakuan.

Keterangan :

$\mathrm{KP}_{1}=$ Kelompok penyajian materi belajar guru (model hidup) pada tingkat kemampuan gerak dasar tinggi

$\mathrm{KP}_{2}=$ Kelompok penyajian materi belajar guru (model hidup) pada tingkat kemampuan gerak dasar rendah

$\mathrm{KP}_{3}=$ Kelompok penyajian materi belajar video compact disk pada tingkat kemampuan gerak dasar tinggi

$\mathrm{KP}_{4}=$ Kelompok penyajian materi belajar video compact disk pada tingkat kemampuan gerak dasar rendah.

\section{PENUTUP}

\section{Kesimpulan}

Berdasarkan hasil penelitian dan hasil analisis data yang telah dilakukan, dapat diperoleh kesimpulan sebagai berikut:

a. Ada perbedaan pengaruh yang signifikan antara penggunaan media penyajian materi belajar guru (model hidup) dan video compact disk terhadap prestasi belajar pencak silat kategori tunggal. Pengaruh penyajian materi belajar video compact disk lebih baik dari pada guru (model hidup). 
b. Ada perbedaan yang signifikan prestasi belajar pencak silat kategori tunggal antara mahasiswa yang memiliki kemampuan gerak dasar tinggi dengan kemampuan gerak dasar rendah. Prestasi belajar pencak silat kategori tunggal pada mahasiswa yang memiliki kemampuan gerak dasar tinggi lebih baik dari pada yang memiliki kemampuan gerak dasar rendah.

c. Terdapat pengaruh interaksi yang signifikan antara penggunaan media penyajian materi belajar dan tingkat kemampuan gerak dasar terhadap prestasi belajar pencak silat kategori tunggal.

(1) Mahasiswa yang memiliki kemampuan gerak dasar tinggi lebih cocok jika diberikan penyajian materi belajar video compact disk.

(2) Mahasiswa dengan kemampuan gerak dasar rendah lebih cocok jika diberikan penyajian materi belajar guru (model hidup).

\section{Saran}

Berdasarkan hasil penelitian ini maka kepada pengajar dan pelatih diberikan saran-saran sebagai berikut:

a. Penyajian materi belajar video compact disk memiliki pengaruh yang lebih baik dalam meningkatkan prestasi belajar pencak silat kategori tunggal, sehingga pengajar dan pelatih lebih memilih media penyajian materi belajar dengan penggunaan video compact disk dalam upaya meningkatkan hasil prestasi belajar pencak silat kategori tunggal.

b. Pengajar disarankan agar mengembangkan media penyajian materi belajar dengan penggunaan video compact disk dalam rangka meningkatkan hasil penyajian materi belajar keterampilan pencak silat kategori tunggal, khususnya prestasi belajar bermain.

Penerapan penggunaan media penyajian materi belajar prestasi belajar pencak silat kategori tunggal untuk meningkatkan prestasi belajar pencak silat kategori tunggal, perlu memperhatikan faktor kemampuan gerak dasar

\section{DAFTAR PUSTAKA}

Annarino, Anathony A. Charles C. Cowell and Helen W. Hozelton. 1980. Curriculum Theory and Design in Physical Education. St. Louis, Miss : The C.V. Mosby Company.

Arief S. Sadiman dkk, 2008 : Media Pendidikan, Jakarta, PT Raja Grafindo Persada.

Brooks, G.A \& Fahey, T. D. 1984 : Exercise Physiology Human Energetics and It's Application. Canadan: John Wiley \& Sons Inc. 
Broer, Marion R. And Ronald F. Zernicde. 1979. Efficiency of Human Movement. Philadelphia : W.B. Sounders Company

Baumgartner, T.A., Jackson, A.S. 1991. Measurement for Evaluation in Physical Education and Exercise Scienc. USA: Wm.c. Brown Communication, Inc.

Depdiknas. 2006. Kurikulum Tingkat Satuan Pendidikan. Jakarta : Departemen Pendidikan Nasional

Drowatzky, John N. 1975. Motor Learning : Principles and Practices. Minncapolis. Minnesota : Burgess Publishing Company.

Espenchade, Anna S. And Heler M. Eckert. 1980. Motor Development. Toronto : Charles E. Merill Publishing Company.

Fleishman, Edwin A. 1965. The Structure and Measurement of Physical Fitnes. Washington, DC : Prentice Hall Inc.

Gagne, Robert M. 1977. The Conditions of Learning. $3^{\text {rd }}$ Edition. New York : Holt, Rinchart and Winston.

Glass, Gene., and Hopkins, D. Kenneth. 1984. Statistical Methods in Education and Physicology, Second Edition, New Jersey : Printies Hal. Inc.

Harrow, Anita J. 1977. A. Taxonomy of The Psychomotor Domain. Second Edition. New York : David Mc. Kay Company Inc.

Http://id.wikipedia.org/wiki/Cakram Padat

Http://www.depdiknas.go.id/Jurnal/44/Jacob.htm

Johansyah Lubis, 2004 : Pencak Silat : Panduan Praktis. Jakarta : PT Raja Grafindo Persada.

Johnson, B. L. \& Nelson, J. K. 1986. Practical Measurement for Evaluation in Physycal Education. New York: Macmillan Publishing Company.

Kotot Slamet Riyadi, 2003. Teknik Dasar Pencak silat Tanding. Jakarta : Dian Rakyat

Lou Anne Johson, 2005 : Pengajaran yangkreatif dan menarik: Alih Bahasa Dani Daryani, Jakarta PT Macanan Jaya Cemerlang.

Magill, Rchard A. 1980. Motor Learning : Concepts and Applications. IOWA : Wm.C. Brown Company Publishers. 
Mathews, Donald K. 1973.Measurement in Physical Education. Philadclphia : W.B. Saunders Company.

Mosston, Muska and Ashworth. 1994. Teaching Physical Education. Fourth Edition. Mac. Millan Publishing Company. New York USA.

Mulyono B \& Sarwono, 1994. Tes dan Pengukuran, Jakarta : Departemen Pendidikan dan Kebudayaan, Direktorat Jenderal Pendidikan Dasar dan Menengah, Direktorat Pendidikan Guru dan Tenaga Teknis Bagian Proyek Penataran Guru Pendidikan Jasmani dan Kesehatan SD Setara DII.

Nurhasan, 1986. Tes dan Pengukuran Modul 1-3, Departemen Pendidikan dan Kebudayaan, Universitas Terbuka.

Rusli Lutan. 1988. Belajar keterampilan Motorik. Jakarta : Depdikbud, Dirjendikti Proyek Pengembangan LPTK

Rusli Lutan dkk. 1992. Manusia dan Olahraga. Bandung: ITB dan FPOK IKIP Bandung.

Rusli Lutan. 1988. Belajar Ketrampilan Motorik Pengantar Teori dan Metode. Jakarta: Depdikbud. Dirjendikti.

Rusli Lutan dan Adang Suherman. 2000. Perencanaan Pembelajaran Penjaskes. Jakarta: Depdikbud. Direktorat Jenderal Pendidikan Dasar dan Menengah. Bagian Proyek Penataran Guru SLTP Setara D-III.

Schmidt, R.A. 1988. Motor Learning \& Performance. United States of Amerika : Human Kinetic Publisher.

Singer, R. N. 1980. Motor Learning and Human performance. London : Collier Macmillans Publisher.

Sudjana. 1994. Desain dan Analisis Eksperimen. Eisi III. Bandung : Penerbit Tarsito 1996. Metoda Statistika. Edisi Ke-6 Bandung : Penerbit Tarsito.

Sudjana, Nana. 2000. Dasar-dasar Proses Belajar Mengajar. Bandung : PT. Sinar Baru Agresindo.

Sugiyono, 2008 : Metode Penelitian, Kuantitatif, Kualitatif dan $R \& D$, Bandung CV. AlfaBeta

Surachmad, Winarno. 1992. Pengantar Interaksi Mengajar Belajar. Bandung : Penerbit Tarsito. 
Sukintaka, 2004. Teori Pendidikan Jasmani, Filosofi Pembelajaran dan Masa depan. Bandung : Yayasan Nuansa Cendekia.

Sugiyanto, 1998. Perkembangan dan Belajar Motorik. Jakarta: Depdikbud. Direktorat Jenderal Pendidikan Dasar dan Menengah Bagian Proyek Peningkatan Mutu Guru Penjaskes. SD Setra D-II.

Sugiyanto \& Sudjarwo. 1992. Perkembangan dan Belajar Gerak. Jakarta: Depdibud. Proyek Penataran Guru SD Setara D-II. Bagian Proyek Penataran Guru Pendidikan Jasmani SD Setara D-II.

Sugiyanto dan Agus Kristiyanto. 1998. Belajar Gerak II. Surakarta: UNS Press.

Sugiyanto, 1999. Belajar Gerak. Surakarta : UNS Pres

Toho Cholik M. dan Rusli Lutan. 2001. Pendidikan Jasmani dan Kesehatan. Bandung: CV. Maulana.

Yudhi Munadi, 2008 : Media pembelajaran : Sebuah Pendekatan Baru: Cipayumg- Ciputat, Gaung Persada (GP) Press.

Waharsono, 1990. Perkembangan dan Belajar Gerak, Jakarta : Departemen Pendidikan dan Kebudayaan, Direktorat Jenral Pendidikan Dasar dan Menengah 